Jonas Hassemer*

\title{
(Meta-)communicative work in a counselling centre for refugees: reiteration, erasure and agency
}

https://doi.org/10.1515/ijsl-2020-0092

Received September 17, 2020; accepted June 1, 2021

\begin{abstract}
We have no apartments is a phrase repeated over and over again at the counselling centre for refugees on housing matters based in Vienna, Austria, where I conducted ethnographic fieldwork. Based on an analysis of processes of entextualisation, de- and recontextualisation in the reiterative, discursive chain, this paper traces the emergence of an institutional regime of communication and the ways institutional actors - counsellors and volunteers - produce, navigate and reproduce this regime by engaging in (meta-)communicative work. The analysis shows how individual agency is both contingent and co-productive of institutional order and social order more generally. With this contribution, I propose Judith Butler's concept of the postsovereign subject as a way to understand the relations between "local" practices and wider processes of trans-situational meaning-making.
\end{abstract}

Keywords: citationality; communicative work; professionalism; recontextualisation; social work

\section{Introduction}

We have no apartments. While doing ethnographic fieldwork at the Beratungsstelle Wohnen ('housing counselling centre')', a counselling centre (henceforth CC) specialising in housing matters for refugees in Vienna, Austria, I heard this phrase being repeated again and again by employed counsellors and volunteers, in different variants and translations, among themselves and in contact with clients and other external interlocutors.

1 This is a pseudonym, as are all participants' and street names.

*Corresponding author: Jonas Hassemer, University of Vienna, Vienna, Austria; and University of Bonn, Bonn, Germany, E-mail: jonas.hassemer@univie.ac.at. https://orcid.org/0000-00028521-4934

¿ Open Access. @ 2021 Jonas Hassemer, published by De Gruyter. (c) BY the Creative Commons Attribution 4.0 International License. 
Initially the CC had functioned as a broker between real estate owners and asylum seekers who aspired to live in a private home. Under the pressure of changing welfare and migration policies and a lack of resources, the $\mathrm{CC}$ reoriented to offer counselling on matters related to housing. Tracing the reiterated use (Butler 1997; Goodman et al. 2014; Nakassis 2012) of the phrase we have no apartments in ethnographic data (observational notes, institutional documents, photographs and interviews), I explore how denying the availability of housing on the side of the $\mathrm{CC}$ became an institutional "frontstage" (Goffman 1959) communication regime at this moment of institutional change. The focus of my analysis lies on the counsellors' and volunteers' professional agency in this transformation process: how are their situated positioning practices (Spitzmüller et al. 2017) implicated with an emergent order in discourse beyond the scale of a single event (cf. Wortham and Reyes 2015)? Their work, I argue, is both communicative and meta-communicative: "speakers not only act" - for instance, by uttering the words we have no apartments - "but [they] also act on their (speech) acts by working to establish how their verbal performances are to be interpreted" (Carr 2011: 159) by commenting on, negotiating and regimenting speech in its communicative form and practice - in short, by communicating on communication. Thus, not only do counsellors and volunteers deploy their communicative repertoires as resources of labour (Boutet 2008; Dlaske et al. 2016; Duchêne 2011), but they also uphold said communication regime across frontstage encounters by working on their communication (cf. Carr 2011). I argue that (meta-)communicative work is ambivalent in terms of agency for the counsellors and volunteers at the CC: while it opens up a certain leeway of action both on an individual (to navigate the situation, to "do one's job") and an institutional level of scale (to continue the operation under changing conditions), it also comes with buying into neoliberalising discourses which drive the process of refashioning the $\mathrm{CC}$, undermining institutional agents' activist conceptions of their work, as well as threatening the existence of the CC.

The CC at the centre stage of my ethnography is run by one of the major nongovernmental organisations which have a pre-eminent role in refugee support in Austria. Alongside other organisations, they are commissioned by the state with services for asylum seekers, persons under subsidiary protection or with a humanitarian right to stay and recognised refugees. In Vienna, these services are funded by the Fonds Soziales Wien ('Vienna social fund'). The institutionalisation of non-governmental refugee support in proximity to the state comes with ideological tensions between the agendas of political advocacy on the one hand, and service-provision on the other (cf. de Jong and Ataç 2017: 31).

In spring 2016 when I started my fieldwork, the CC was in midst of a shift from material support to communicative services. Earlier, in 2014, the CC had started out as project with the purpose to bundle and manage accommodation offers from private real estate owners to asylum seekers. The CC had functioned as a broker, a point of contact and gatekeeper for two parties: it communicated the possibility for asylum seekers to 
live in a private home outside the state-sponsored accommodations ("camps") to the asylum seekers themselves and to the wider public, acquiring both "clients" and "donors" for its project. Based on a set of criteria (such as location, condition and cost), the staff decided whether or not to include accommodation offers in their portfolio, selected clients from a waiting list, "matched" them to the offers and watched over the legality of contractual relationships. For a brief period, the organisation performed an active humanitarian intervention in a relatively unconstrained space where the state infrastructures would fail in the course of 2015: the state-sponsored "camps" were direly overcrowded and the existing structures unable to deal with the situation. The refugee camp Bundesbetreuungsstelle Ost in Traiskirchen, Lower Austria, where the project started, became emblematic of the catastrophic dwelling conditions in the statesponsored camps (Bundesministerium für Inneres 2015; Schmidt 2015).

But in the context of a changing public and political discourse on migration and asylum in Austria (Meinhart et al. 2018), the initial euphoria in which private real estate owners had offered their vacant property to asylum seekers in 2014/2015 soon shrank. At the same time, federal and national policies regulating the possibility for asylum seekers to live in private accommodation became ever more constraining (culminating in the Fremdenrechtsänderungsgesetz 2017 'amendment to the alien law 2017', Bundesministerium für Inneres 2017). Under threat of being closed down, the CC shifted its purpose from the provision of material resources (housing) to that of communicative services - assistance with house-hunting, rent contracts, disputes with landlords and neighbours, application for housing-related welfare benefits etc. In addition, a volunteers' project was set up - which I will call the Recherche-Eck ('search corner'). Here, volunteers - many of whom first came as clients themselves - assisted clients while they searched for apartments online. Counselling relied to a high degree on the work of two part-time employed interpreters (Farsi and Arabic/Armenian) and a large, fluctuating number of volunteer interpreters (overlapping with the group of volunteers at the Recherche-Eck).

Yet, after the reorientation from brokering to counselling, the demand for private accommodation did not simply cease to exist and clients continued to ask to be allocated an apartment. Indeed, smaller numbers of housing offers continued to be acquired by the CC and were used for a restricted category of “emergency cases". For the counsellors, this exacerbated the ethical quandaries already entailed in their previous role as brokers - having to decide who gets an apartment and who not - and a perceived lack of agency towards the precarious living conditions of their clients. I often observed how counsellors tried to remedy this situation by orienting to their clients' affective needs, trying to "give them hope" despite their situation or to let them vent their anger. Apart from such individual efforts, a communicative apparatus was put in place to regulate and cover up the continuing brokering activities. This apparatus was considered necessary in order to partially maintain the original agenda of giving access to private housing on a much smaller scale. It consisted in standardising 
and scripting the counselling practices through a Beratungsleitfaden ('counselling guidelines'), regulating affect in counsellor-client relationships by formalising Beziehungsregeln ('relationship rules'), emphasising the concept of Abgrenzung ('setting boundaries [towards the client]'), and instituting a regime of frontstage communication in which the phrase we have no apartments was an emblematic element (cf. Codó 2008 for similar observations).

With housing as a "crowd-sourced" resource running short, the work at the CC had thus changed - shifting responsibilities (for the accommodation of asylum seekers ${ }^{2}$ ) to the individual client of welfare institutions and foregrounding professionals' (and clients') communicative and affective repertoires as key issue of social work (cf. Del Percio 2016). While a general tendency in welfare systems towards such shifts in responsibilities and logics of service has been observed by scholars of neoliberal governance and language (cf. Martín Rojo and Del Percio 2019; see also Lessenich 2008), my aim here is to zoom in on the specific semiotic mechanisms of the regime of frontstage communication enacted by the counsellors and volunteers at the CC. My aim is to understand how, why and to what effects counsellors and volunteers continued to repeat the phrase we have no apartments - to each other, to their clients as well as to colleagues from other organisations. I argue that such (meta-)communicative work is part of an institutional response to the changing position of the $\mathrm{CC}$ within the politicaleconomic conditions of refugee support and a way in which institutional agents obtain an ambivalent agency in these circumstances. (Meta-)communicative work enables the work of the CC both on an individual and an institutional scale, but, as we shall see, it concomitantly allows neoliberal logics to percolate the encounters at the CC.

With this contribution, I argue that the notion of reiteration from linguistic anthropology (Agha 2007; Bauman 2004; Bauman and Briggs 1990; Goodman et al. 2014; Nakassis 2012) and post-structuralist language philosophy (Butler 1997) allows to analytically grasp both the semiotic mechanisms involved in (meta-)communicative work and the inherent ambivalence of its effects on speaking subjects' agency on an individual and institutional level of scale. In methodological terms, the notion thus points to the subject as a relevant analytical category for understanding the scalar dynamics between situated practice and translocal phenomena of social or discursive order (Pritzker and Perrino 2021; Spitzmüller et al. 2017). First, I elaborate on the concepts of (meta-)communicative work and reiteration (Section 2). The following sections trace several instances of recontextualisation of the phrase we have no apartments along the discursive chain. I start by anchoring the phenomenon in the recent history of the $\mathrm{CC}$ (Section 3), tracing how the phrase became a stabilised, reiterable message in the time to follow, and delineating the ways this process has

2 This is a development to which the NGO's initial agenda - paving the way for asylum seekers to private accommodation - paradoxically contributed as well. 
shaped the discursive reality of the CC (Section 4). Then I engage with the ways counsellors, volunteers, and clients navigate the discursive reality created through (meta-)communicative work (Section 5) and I connect this to workers' construals of the institutional changes (Section 6). Finally, I discuss the analytical implications of my findings (Section 7).

\section{Concepts: (meta-)communicative work and reiteration}

My analysis of the semiotic mechanisms involved in the regime of frontstage communication and its ambivalent effects on the counsellors' and volunteers' agency rests on two conceptual pillars, (meta-)communicative work and reiteration, which I introduce in detail below.

The shift from brokering for apartments to the provision of communicative services at the CC did not so much entail that the communicative dimension of work grew in substance - the previous activities, such as mediating between clients and donors, had largely consisted in communication too. Rather, metacommunication thrived in this process, as an increasing attention was given to the communicative encounter and affective relationship between clients and counsellors during staff meetings and in regulatory efforts such as the above-mentioned counselling guidelines. The term (meta-)communicative work thus highlights the metapragmatic dimension of communicative work by which speaking subjects position themselves and engage in meaning-making (cf. Spitzmüller et al. 2017). By doing (meta-)communicative work, counsellors and volunteers contribute to the reproduction of the institution (cf. the notion of institutional work, Lawrence et al. 2009) under the discursive contingencies of the wider political-economic context, such as the neoliberal tendencies in welfare policy. My usage of the term borrows from two sources: The notions of metalinguistic labour (Carr 2011) and of paroled'œuvre ('wordforce'; Duchêne 2011), which offer a semiotic and a politicaleconomic perspective on language at work respectively.

By metalinguistic labour, Carr (2011) refers to the effort therapists in a rehabilitation programme put into shaping the talk of their clients according to a dominant language ideology of inner reference. She shows how the work invested by therapists in linguistic form and practice has the double effect of leading to conformity with this language ideology and of "filter[ing] away clients' institutional critiques and other social commentary" (Carr 2011: 126) as it allows the clients to locate problems and obstacles only within themselves. The metapragmatic attention and the implication with institutional integrity is what relates this concept to what I call (meta-)communicative work. With the notion of paroled'œuvre, Duchêne (2011: 84) draws attention to the ideological continuity between 
the regimentation of manual labour in the industrial sector and communicative labour in the service sector, drawing on the work of, among others, Boutet (2008) and Heller (2003). With a critical view on the economic valorisation of languages and communicative practices, the central question is who is able to profit from engaging in communicative work and under which conditions this is the case (Duchêne 2011: 82). The concept thus directs the attention to dimensions of symbolic and economic inequality, the distribution of risks, workloads and returns stimulating, for instance, the question of who is "carrying the weight" in the process of refashioning services at the CC.

How can we analytically grasp semiotic mechanisms entailed in the repetition of the phrase we have no apartments with its ambivalent effects on the counsellors' agency in the specific institutional and political-economic context? This question relates to a wider theoretical problem, namely: How does trans-situational meaning (Wortham and Reyes 2015) - phenomena of order, typified practice, objects and subjectivities - relate to situated (inter)action? What does this mean for a subject's agency, i.e. their leeway to act and position themselves? These are, first of all, questions of scale: First, the questions themselves organise the social in a scaled manner, namely in terms of abstractedness and extension in time and space (cf. Carr and Lempert 2016). Second, they orient the analytic interest towards the way subjects draw on scalarity in their positioning, as they construe the world in terms of situated, singular events and individual actors or rather trans-situational, abstracted categories of events and actors (Blommaert 2007: 3-7; Pritzker and Perrino 2021).

But crucially in our case, it is not just that the abstract statement we have no apartments was being used to fence off clients' individual concrete requests, but that this happened over and over again, starting from a moment where the existence of the CC was at stake. This repetition, I argue, entails more than just the cumulative effect of separable acts by sovereign speaking subjects, but generates slippages of meaning which are neither explicitly intended by speakers nor entirely random as they tend to reproduce logics of dominant discourses - for instance, the above-mentioned responsibilisation of the client in a neoliberalising welfare state. Rather than as a sovereign author-speaker of its "own” acts of speaking, the speaking subject, then, is best understood as a postsovereign subject (Butler 1997: 139). This means that its agency relies on a discursive context it cannot fully control. This conceptual argument requires further clarification of its theoretical foundations, namely the notion of reiteration.

By reiteration, I mean a generic concept which refers to everything on a continuum from explicit uptake (i.e. "citation”) to regularities across time construed expost (cf. Bauman 2004: 5; Nakassis 2012: 627). It may involve all sorts of linguistic phenomena, a sequence of signs (such as the phrase we have no apartments) or a semiotic form (e.g. a genre) (Goodman et al. 2014: 450). On the one hand, I draw on 
the linguistic anthropological notions for an analysis of contextual dynamics in reiterative practice, i.e. to analytically grasp how and why indexical meanings linked to the phrase we have no apartments become stabilised (cf. Wortham and Reyes 2015) and by which semiotic mechanisms they spread across scalar levels (also described as fractal recursion, Gal and Irvine 2019: 127). Entextualisation denotes "the process of rendering discourse extractable, of making a stretch of linguistic production into a unit - a text - that can be lifted out of its interactional setting” (Bauman and Briggs 1990: 73). This process is one of objectification: transformed in an "object”, a stretch of discourse becomes available for decontextualisation - to be taken out of its former context - and recontextualization - to be put it in another context, which means it is available for all sorts of metapragmatic commentary (Bauman 2004: 4). The Butlerian notion of reiteration, on the other hand, offers a model of agency in semiotic practice. According to this model, the speaking subject draws on signs which have been used before - it cannot but "cite" them. Butler (1997) conceives of reiteration as relations of citationality (cf. Derrida 1972), thereby conflating (explicit) citation and other forms of reoccurrence as Nakassis (2012) critically observes. Through an erasure of this historical contingency of the subject's acts of speaking (Butler 1997: 49-52), the repeated form comes to be conceived as an instantiation of an authoritative model or "norm" (see Butler 2004: 40-56) instead of as a mere token in a reiterative chain. In other words: it is upscaled (Blommaert 2007: 6). In order for speech to index a speaking subject as its author (Duranti 2006: 455), the citationality of their speech needs to be erased. To trace reiteration in practice then shows not only the subject's dependency on its context, but it expands this context by analytically including bits of its erased historicity. This allows to analyse not only how meaning is configured across events (as proposed by Wortham and Reyes [2015], who draw on linguistic anthropological notions of reiteration), but also how and with which consequences the postsovereign speaking subject subjects itself to (read: is at the same time enabled and constrained by) discourse by engaging in its reiteration. In the remaining sections, I follow pathways (Wortham and Reyes 2015: 66) reconstructed in my data between discursive events in which the phrase we have no apartments was recontextualised.

\section{Institutional change: between brokering and counselling}

In May 2016, the CC moved its operation to new premises located in an outer residential district of Vienna. I will do as the counsellors and refer to it by the name of the street where it is located - let us call it Beckergasse. The premises were shared with 
another project unit of the same NGO. Before that, the CC had used two separate premises, one as a back office (the Mühlengasse) and the other as a counselling space (the Seestraße). The latter was installed on the rather dilapidated premises of a former bank branch. The relocation coincided with an important change of programme - quoting from the minutes of a staff meeting at that time (Example 1).

Example 1: Excerpt from the minutes of the staff meeting on 10 May 2016 (my English translation).

Ab Juni wird es Flyer geben für die Seestr. wegen From June on, there will be a leaflet for Seestr Schluss und überhaupt. CAMBIA MODUS OPER- [aße] because of the end and everything. ANDI. Keine Wohnungsvermittlung mehr in der CAMBIA MODUS OPERANDI [Italian and Latin: Beckergasse. 'mode of operation changes']. No brokering for apartments anymore in Beckergasse.

This short note from the minutes renders an important change in condensed form: a re-orientation from brokering apartment rentals to mostly counselling on housing-related issues. A few days later, following this entextualisation of the change process, an information signboard (Figure 1) was displayed outside Seestraße in four language versions - German, English, Arabic and Dari/Farsi ${ }^{3}$ in terms of the language "names" habitually used at the CC (cf. Urciuoli 2016).

The announcement can be analysed as an act of recontextualisation of "backstage" (Goffman 1959) discourse on the "frontstage" of the institution, involving communicative labour by several actors, staff members and translators. As far as I can reconstruct from the minutes of the preceding staff meetings, the text was adapted from an earlier announcement, which I am no longer able to retrieve. Moreover, the denotational text of the announcement echoes the earlier practice in counselling, i.e. prior to the institutional reorientation, where the counsellors would explain to the clients that the housing opportunities where donated by third parties (and not owned by the NGO), emphasising the scarcity of available housing in Vienna. It is thus likely that this is not the "original” version of the phrase (which of course has a historicity in itself), but one that has been put in the very defining context of the closing of the premises in Seestraße.

The entextualisation conveys a perspective (Gal and Irvine 2019: 88) on the relationship between the availability of resources (housing offers) and the communicated decision to discontinue the service (brokering), as well as to refashion the service (consulting, support and guidance). The relationship is constructed as contingent and

3 In institutional metalinguistic discourse, the language categories of "Dari" and "Farsi" are not distinguished effectively. To my informant, a speaker of an Iranian variety, the text in Example 2 is recognisable as "Dari" due to the choice of register-specific terms. 


\section{[Logo/name of NGO]}

مشاوره يراى متقاضيان بناهندكى و بِناهندان به رسميت شناخته شده كه در جستجوى خاته هستند

اسنثار ات للاجئبن المعترف بهم و لطالبي اللجوء

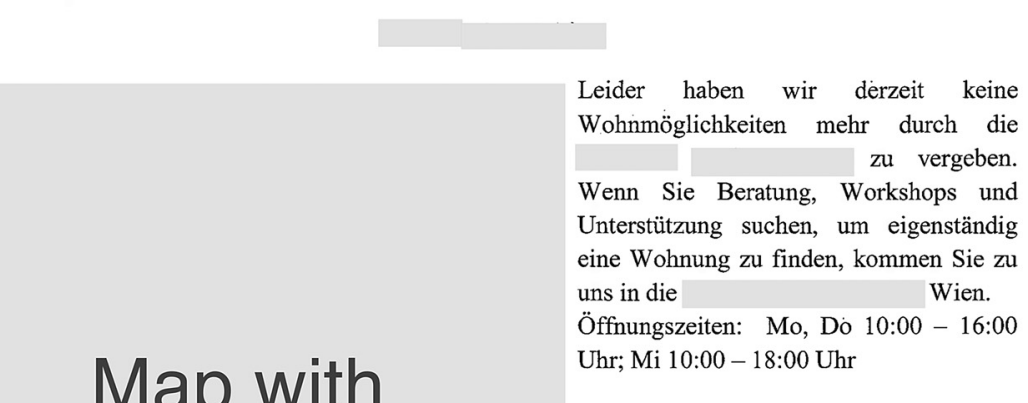

We regret to inform you that we no longer location of the counselling centre

have housing offers at

\section{If you wish to participate}

in workshops, have consulting, support and guidance concerning your search for apartments, you can come to our office at

Wien. We are open on Mondays and Thursday between 10a.m. and 4 p.m. as well as on Wednesday from 10a.m. to 6p.m.

$$
\begin{aligned}
& \text { يؤسفنا أن نعلن أنه لم يعد يتوفر عروضات للسكن لاى } \\
& \text { إذا كتتم ثرغبون } \\
& \text { الحصول على استثارات او مساعدة وتوجيه فيما يتعلق } \\
& \text { في بحثكم عن السكن، يمكنكم أن ثائوا اللمى مكتبنا في } \\
& \text { Wien } \\
& \text { مواعيد الدوام: - مائ } \\
& \text { الاثثين: 10:00- 16.00 } \\
& \text { الاربعاء: 10:00- 18:00 }
\end{aligned}
$$

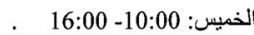

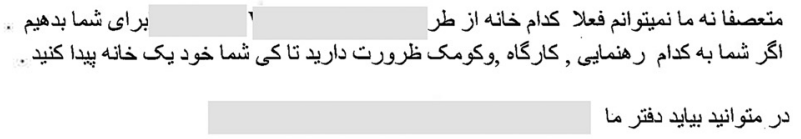

Figure 1: Quadrilingual note displayed outside the bank premises upon their closing (collected 20 June 2016). Sensitive information is hidden, borders cropped. 
contiguous. Even if the announcement is separable as a text, a range of text-level phenomena are coherent with the observation that it is rather specific in its contextualisation. For instance, the embedding clauses in the English and Arabic versions (we regret to inform you ... and ... يؤسفنا أن نعن أنه (ئه ) entextualise a specific interactional

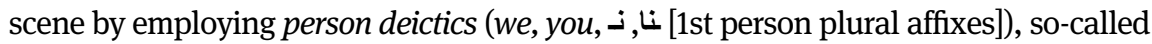
shifters (Silverstein 1976), which entextualise a participation framework, verba dicendi ('verbs of speaking', to inform, أَعَلَنَ ['to inform']) which entextualise a scene of utterance (Agha 2007: 20) and verba sentiendi ('verbs of feeling', to regret and أَسِفَ ['to regret']) which entextualise an affective stance connected to the utterance. Furthermore, the temporal deictics in the German, English and Dari/Farsi version derzeit ('currently'), no longer, فعل ('now') etc. - have their construable referents in a specific interactional moment in time and space (Agha 2007: 38), namely on the glass pane of the former bank branch in the early summer of 2016. The announcement thus carries traces of its interactional context even when decontextualised (and recontextualised, as in this article where it is framed as a piece of data).

The CC “officially" moved from brokering to counselling proper - at least this is how it was communicated to clients, other NGOs and partners. Yet the CC continued to collect accommodation offers and continued to allocate apartments to those clients who were considered "emergency cases". While almost everybody, including the clients, knew about this practice, a strict policy was put in place not to mention the continuing existence of housing opportunities at their disposition. This led to a (fractal) "split" between what was sayable "backstage" and "frontstage", (re-)producing the fuzzy, yet consequential boundaries between the inside and the outside of the institution, "emergency" and "non-emergency" cases, etc. Such boundaries do not necessarily fit the complexity and affordances of institutional life: First, it happens frequently that volunteer interpreters - for instance, when searching for an apartment - become clients of the CC which destabilises the neat distinction between "frontstage" and "backstage". Second, there are many views among the staff of what is to be counted as an "emergency case". This introduces almost unsolvable questions about rationales and morals of distribution. And third, the voices of former clients who were lucky enough to be allocated an emergency apartment, which circulate among clients in and beyond the walls of the CC call into question the whole regime of sayability. Thus, the reiterated phrase serves to exert control not just over the circulation of knowledge, but more so over the ways of speaking about that knowledge through an erasure of those aspects of institutional life which would complicate the clearly drawn boundaries.

\section{Entextualisation: a stabilised message}

While the signboard displayed outside the premises at Seestraße (Figure 1) was contextualised in a specific moment of time and space of which it was coconstitutive - the moment of institutional change - it became subject to further 
processes of entextualisation and recontextualisation in what followed. Entextualisation entails selection, re-arrangement or similar which respond to situated perspectives and interests (see Urban 1996). In this case it brought about a reduction of deictic anchoring which allowed the subsequent recontextualisation in diverse "newly arising" circumstances, as a solution to different, yet related institutional problems. In what follows, I consider a few instances of recontextualisation of the phrase in order to trace how the message became extractable and recontextualisable.

In the waiting room of the new premises at Beckergasse, we encounter some of the denotational text from the announcement (Figure 1) again. Consider the Arabic and Farsi bilingual (Figure 2) and Arabic monolingual signboards (Figure 3). They do not only exhibit a reduction of linguistic variants effectively reducing the range of addressees ${ }^{4}$ (German and English are missing in Figure 2, German, English and Dari/Farsi in Figure 3 as compared to Figure 1), the text also got rid of the temporal deixis and "interactional anchoring” (Agha 2007: 41). Now, it simply

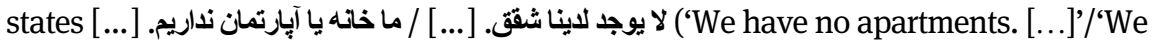
have neither houses nor apartments. [...]'). These are traces of the decontextualisation that allowed the text to become stabilised as a permanent message to clients in the waiting area.

$$
\text { لا بوجد لدينا شققى. نمن نقدم نصائح فقط. ونساعدك فقط في كيفية البحث عن شقق. }
$$

Figure 2: Bilingual signboard (“Arabic", "Dari/Farsi”) in the waiting area (photographed 8 November 2016, translated, emph. in orig.) "Arabic” (vertical lines indicate line breaks): "We have no apartments. | We can only offer advice. And we only help you with how to search.' "Dari/Farsi”: 'We have neither houses nor apartments. | We only advise and guide you to find a house or apartments.'

4 However, the language choice reflects not only assumptions underlying recipient design (e.g. that clients from Somalia often understand Arabic), but also the differential availability of the relevant linguistic labour force for translations in various languages. 


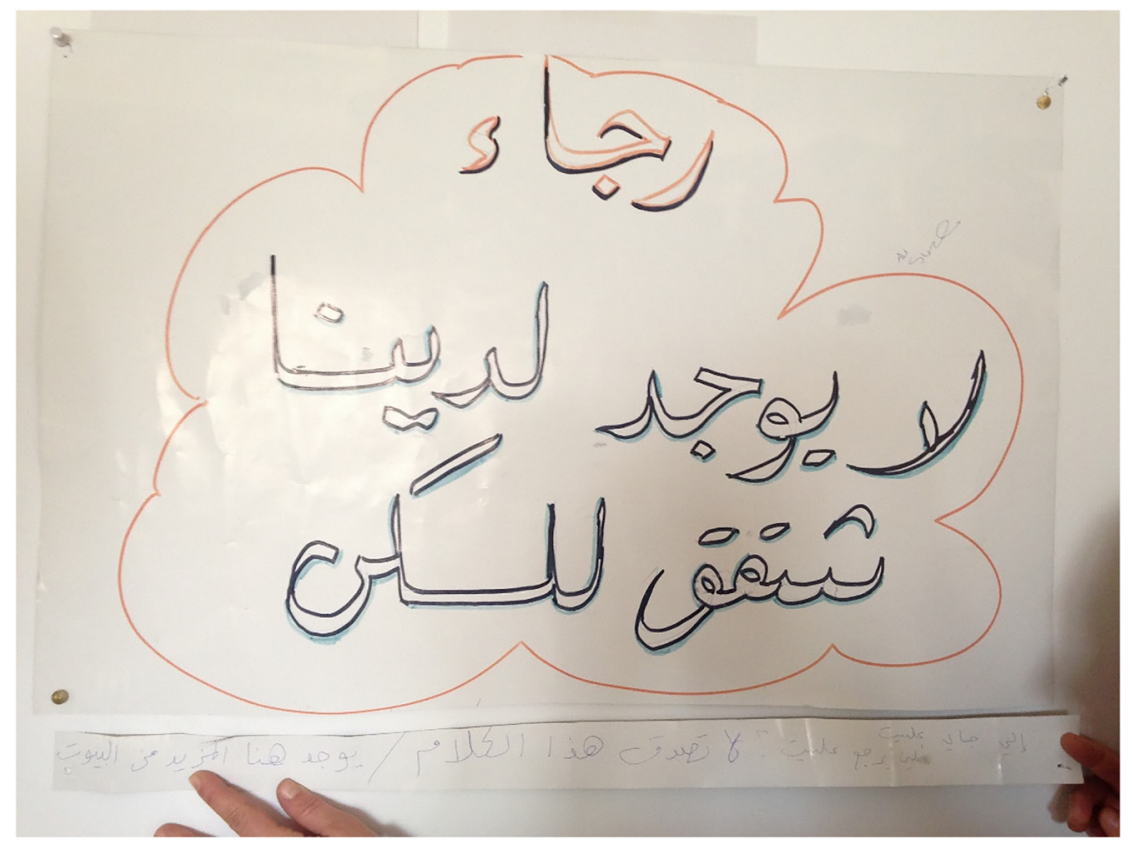

Figure 3: Monolingual ("Arabic") signboard in the waiting area (photographed 29 November 2016): 'A request [or: please] | we do not have | apartments.'

Figure 3 gives an interpretive hint as to why such a message was made permanent. Below the signboard, there is a paper strip with a response by a visitor (or probably more than one) to the CC. It was cut away - on the photograph it is being held where it was placed before. It reads (with my own translation):

01

02

03

04

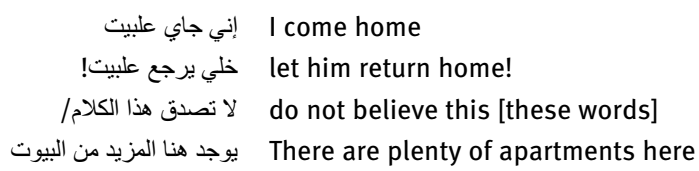

The first two lines seem to be written by a different person (or two) than the last two: as a response to an expression of discontent or even desperation (lines 01-02) follows the invitation not to give credit to the "official" message above, stating that the CC does have apartments (lines 03-04). The uptake of the "official truth" documents: the knowledge that there are apartments, that brokering continues at least somehow, circulates among clients. And institutional agents are aware of it: I 
heard counsellors and volunteer interpreters describe the clients' uptake in the following ways: "They don't believe us", "they think we have apartments”, "they think if they just come here often enough, they'll get one” etc. In spite of the counsellors' awareness that many clients are already aware of the mismatch between the "official truth" and actual practice, the message we have no apartments is upheld. The way of dealing with contestation documented in the photograph (Figure 3) - erasure, here in the form of literally cutting away the unwanted stretch of discourse - speaks of a concern with the way the services of the $\mathrm{CC}$ are rationalised by actors "outside” of its organisational boundaries.

\section{Institutionalisation: professional agency and (meta-)communicative work}

As we have seen above, the phrase we have no apartments returns as part of a continuous work on the representation of the institution among the clients. In this section, I want to inquire about the function the reiteration of this phrase and the perduring erasure reproduced by it has for the counsellors' professional agency. Consider the following discussion (Example 2) which took place at a staff meeting.

Example 2: At a staff meeting (fieldnotes, 4 October 2016).

Yasmin, a counsellor, raises a point: She says in the latest counselling sessions she had conducted, she had increasingly been confronted with the rumour that the counselling centre was back to brokering apartments. "People are coming, saying there are apartments", "I had to justify myself all the time." To which Sara, head of staff, concurs: "Me too, I had to argue all the time". Yasmin concedes that clients simply might be lying, but then Sara and Yasmin ask their colleagues where the rumour might originate from. Till, another counsellor, narrates in constructed dialogue that for strategic reasons, he had proposed unplaceable offers (apartments in small villages faroff) to "whining" clients, adding they would not accept them anyways which was indeed what happened. Sara responds that this would still get around and incite hopes and claims. They then talk about the old (closed) waiting list which is still being used for incoming offers, but which is, Till says, not up-to-date anymore. Cover-up strategies are discussed, to be used in case there was an apartment to be given to a client: (1) Brokering activities/meetings between clients and donors can be held elsewhere; e.g. they might be processed by the team Lower Austria [another project of the NGO] (2) Make the clients believe it was an offer they had found by themselves, orchestrating a ring-back from the donor/landlord. Yasmin tells the others of a case where she had successfully employed this strategy. In conclusion, Till emphasises that none of his strategic offers had led to a contract, but he promises not to continue this practice. 
The conversation starts with a complaint by Yasmin (joined by Sara) and the team is invited to investigate where the supposed rumours come from. Till concedes that there might be a connection to his practice of confronting clients with the lack of acceptable apartments in their data repository. He is asked to stop the practice. This decision shows that erasure is strategic in communication with clients: It is preferred to other, alternative strategies of dealing with the lack of resources, such as Till's confrontational approach. Elaborate strategies are thought through which shall help to cover up the continuing brokering activities. The cover-up strategies are seen as necessary in order to reconcile the brokering with the rest of the institutional agenda. Reiterating the phrase we have no apartments is part of these strategies. It is (meta-)communicative work in the sense that counsellors need to manipulate and monitor their communication according to a regime of sayability, and they do so by communicating the same "truth" over and over again.

The vignette above (Example 2) illustrates the emergence of an institutional response to the situation. The counselling guidelines that were produced since the restructuration of the service (see Example 3) give us the opportunity to see how (meta-)communicative work was institutionalised. Designed in summer 2016 in a multi-staged process with two counsellors preparing a draft and the others commenting on it, they were revised and amplified in early 2018. The part quoted in Example 3, however, remained unchanged. In some formal aspects (e.g. chronological order), the script is an iconic model of an (idealised) encounter with clients. It responds to (actual or anticipated) problems arising from such encounters. Apart from general principles to be followed by the counsellors, the script also specifies a number of issues to be covered, among them to work on the clients' Erwartungshaltung, 'expectations'. This amounts to an institutional self-presentation with the purpose of framing or delimiting the encounter in a specific way. As part of this framing, the script specifies that the non-existence of housing offers should be stated at the beginning of a consultation (Example 3).

Example 3: Excerpt from the counselling guidelines as of June 2016 and February 2018 (my English translation).

- Erwartungshaltung: Was bieten wir an, was - Expectations: What do we offer, what können wir tun? Was nicht? can we do? What not?

- dezidiert offenlegen, dass es keine Wohnun- - $\quad$ to disclose decidedly that there are no gen über uns gibt apartments [to have] from us

- mögliche Angebote: [...]

- possible offers: [...] 
The underlying claim that there are no housing offers is entextualised as a truthful statement in the script. This means that the erasure remains in place even when the text returns "backstage". Of course, one can assume that all counsellors know that information on potential emergency apartments is omitted here - even many clients would. But the fact that no differentiation between types of clients and circumstances is added shows the centrality accorded to this erasure in the institutional regimentation of communication. For instance, the script does not account for the case in which one were to present a client with an emergency apartment, after having repeatedly told them at the previous encounters that there are no housing offers.

Working on clients' "expectations”, effectively redirecting them from material resources (housing) to communicative services (counselling), is a way of keeping the $\mathrm{CC}$ alive in a situation where resources have become scarce. Indeed, before the restructuration, closing down the $\mathrm{CC}$ had been on the table. The reorientation of services advocated for and negotiated by Sara, the head of staff, with the funding bodies and the administration of the NGO ensured its continuation.

But apart from this historical backdrop, which casts the reiteration of the phrase we have no apartments as a continuous attempt to shape the clients' expectations according to a changing logic of service, there is another effect: the phrase ensures that decisions on the continuing distribution of resources are made "backstage", hidden from the clients' view. The strict denial of the availability of housing precludes any question about mechanisms and logics of distribution. It effectively reduces accountability for decisions on who is to receive an apartment. Moreover, it prevents to a certain degree that clients may adapt to the mechanisms of distribution in place, plead their cases and make sure they meet the criteria employed in the decision-making processes on emergency cases. At least superficially, this stands in contradiction to what Sara, the head of staff, told me in an interview about the moral boundaries of service: she said she was convinced that clients had every right "to take advantage" of them - but this too was framed in a communicative sense, in terms of venting their anger about their situation.

Apart from one-to-one counselling situations and workshops, an important space of institutional encounter with clients is the Recherche-Eck (Example 4). The Recherche-Eck was established as a possibility for the clients to receive assistance in the actual process of searching for an apartment. As such, the structure fills a void left by the discontinuation of the brokering activities, as it institutionalises access to the desired resource in an alternative form. Here, clients can get access to a computer and the opportunity to learn to navigate the usual Austrian online real estate platforms, thus applying abstract information on housing contracts etc. received in prior counselling to actual rent advertisements. At least that is the theory. In many cases, as noted by the counsellors themselves on some occasions 
in their staff meetings, the Recherche-Eck risks becoming the preferred solution for a residual category, i.e. clients who just do not find an apartment by themselves, but do not (yet) qualify as "emergency cases". Questions of literacy further complicate the issue.

Example 4: At the Recherche-Eck (fieldnotes 12 June 2018).

As I am working with a client at the Recherche-Eck, I overhear an interaction between Helena (the counsellor in charge of the Recherche-Eck that day), Ismaaciil (a volunteer) and a client in front of a computer. Soon Helena starts to question the use of the client's participation in the activities at the Recherche-Eck: She explains to her that she has to take part in the search process, because this is what they offer at the Recherche-Eck, assistance in the search for housing, not doing the search for her. If that was not what she wanted, the Recherche-Eck would not be the right place for her. At the end of this triadic interaction in which Ismaaciil mostly acted as an interpreter, the client stays and Ismaaciil starts to work with her one-to-one. Afterwards, Helena and Ismaaciil talk about his work with the client. He tells her that the client had repeatedly asked him how she could get an apartment. That acquaintances of her had been given an apartment from the counselling centre. That she did not believe that there were no apartments. That she said she saw no sense in searching. That she was not familiar with computers and emails. That apparently, clients were treated unequally at the counselling centre because some were obviously given apartments and others not. Helena asks Ismaaciil if it was exhausting for him and he concurs. Helena tells him that it was a recurring observation that such questions arise almost only when counselling is conducted in the clients' "mother tongue". She asks me - I had been participating as a bystander - if I had experienced a similar situation before. I reply that indeed I did, yet not to this degree and intensity. Ismaaciil adds that some people would prefer to work with a volunteer who is a native speaker of German. Helena tells him he should go on break, but then she adds that she is sorry, there is another Somali-speaking client waiting outside. She proposes to Ismaaciil that he and I would work together, so he could "just" be the interpreter in the encounter. She asks for my consent as well. I agree but I also ask Ismaaciil whether he feels this would exonerate him, if this was what he wanted to do. He agrees.

The ideological dimension of the communicative work employed in shaping the client according to a changing logic of service reappears at the Recherche-Eck. The scene (Example 4) shows how not only the phrase we have no apartments has become recontextualisable but also the entire differential scheme organising services at the CC. Consider Helena's intervention at the beginning of the encounter, how she differentiates what ought to be part of the service at the Recherche-Eck and what not. As in the restructuring of the $\mathrm{CC}$ as a whole, it is not access to material resources but to communicative ones that is on offer. Helena employs a scheme differentiating the services offered at the CC (counselling) from "illegitimate" expectations (an apartment) for the Recherche-Eck: assistance/ guidance in the search for an apartment versus having someone searching for them. In this scheme the context of the Recherche-Eck maps iconically on the 
overarching context of the CC - the axis of differentiation is "fractally reiterated" (Gal and Irvine 2019: 127). The differentiation is linked to two distinct figures of personhood (Park, this issue): the self-responsible client (legitimate) and the "NGO-dependent" client (illegitimate). The differentiation between the two is also made relevant when discussing who will receive an emergency apartment. Being regarded as someone who "relies on NGOs", i.e. who does not take initiative when they could, can mean that one is not regarded as "deserving". The case reported in Example 4 thus exemplifies how (meta-)communicative work at the CC is ideological work: it takes part in the (re-)production of responsibilised subjectivities in a neoliberalised welfare state (Lessenich 2008). However, it is important to note that these logics are not at all uncontroversial among the staff. And while Helena in this example seems to emphasise the dimension of will or choice, decision-making "backstage" is more nuanced in that a dimension of capability is considered as well.

In addition, the example above shows how communicative work is unequally distributed among institutional actors. As argued elsewhere (Hassemer and Garrido 2020), "languaged" workers (Dlaske et al. 2016) - counsellors and volunteers whose linguistic repertoires are used as a resource by the institution - are especially susceptible to unequal distributions of workload among staff at the CC (see also Duchêne 2011). The episode from the Recherche-Eck (Example 4) shows how this observation is also valid for the kind of communicative work described above.

\section{Professional positioning: workers' selves and institutional order}

The above observations show how (meta-)communicative work allowed counsellors and volunteers to navigate encounters in the process of refashioning services at the CC. However, it did not consolidate the refashioning of services in communicative terms (clients continued to ask for apartments), instead it helped to consolidate a discourse of deservingness and responsibilisation in the encounter with clients. In this section, I look into the positioning of two institutional agents - Sara, the head of staff, and Till, a counsellor - towards the changes they witnessed in their workplace to further situate the phenomenon of (meta-) communicative work. In their construal of the institutional change, Sara and Till refer to two very similar axes of differentiation (Gal and Irvine 2019), with activism on the one end and service provision on the other.

In January 2018, I conducted an interview with Sara, the head of staff. The new government composed of the conservative Austrian People's Party (ÖVP) and the right-wing populist Austrian Freedom Party (FPÖ) had just entered office and the 
preceding government had dramatically restricted the possibilities to hold a private residence for asylum seekers. We talked about the implications of the recent political changes on hiring and staff development when I asked her whether she thought that there was a "different type of people" working in her team now compared to a few years ago. She told me she had observed that the "ideological fighting spirit" was not as present anymore among the staff. With "self-exploitation" being endemic in refugee aid, this decline of an ideological driving force to cope with the everyday frustrations from the job worsened the effects of exhaustion among the staff. She also said that, in her view, the idea of advocacy for the cause of refugees' rights in Austria was being supplanted by questions of "mandate" and legality when planning interventions on behalf of clients. She characterised the new type of worker as someone who was more conscious of the representational function of their institutional role than the former.

Till aligned more with the former, activist type of worker. He was one of the few social workers by training among the staff and in the interview of which a transcribed excerpt is presented below (Example 5) he contrasts two approaches to social work using scholarly terminology: individual case work versus political work aimed at social change (which he associates with a Marxist critique of social work). He thus projects the axis of differentiation to another level on a scale of abstraction, entextualising it in analytical terms and recontextualising it in scholarly discourse. This upscaling (Blommaert 2007) allows him to ground a critique not only of the political developments in Austria but also towards institutional procedures and the structures he is part of.

Example 5: Extract from an interview with Till, a counsellor (9 February 2018). English translation below.

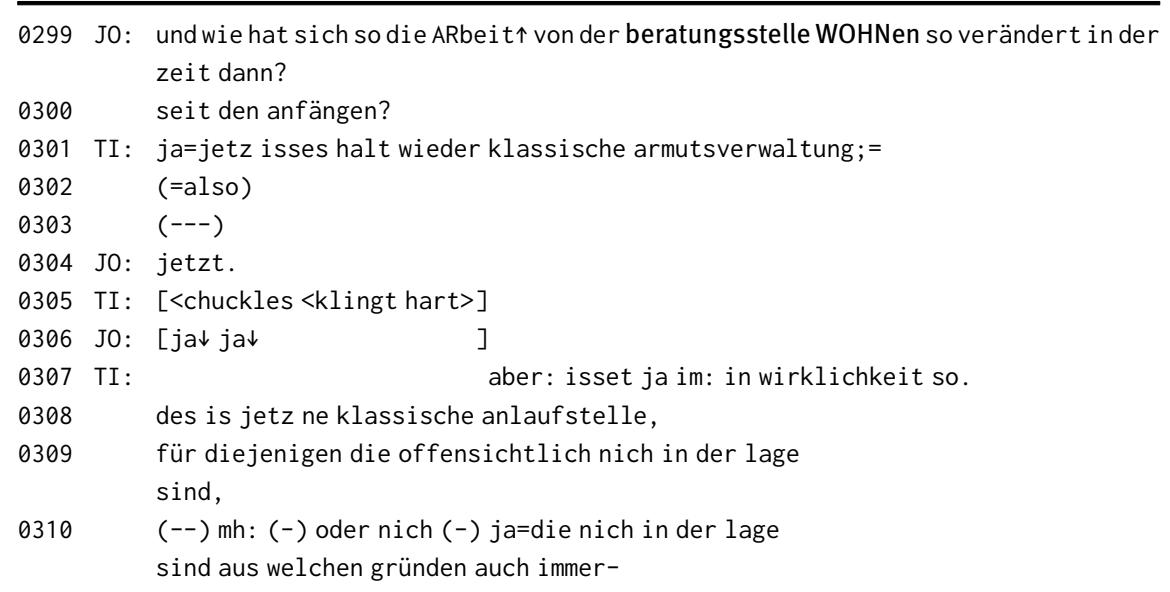




\section{Example 5: (continued)}

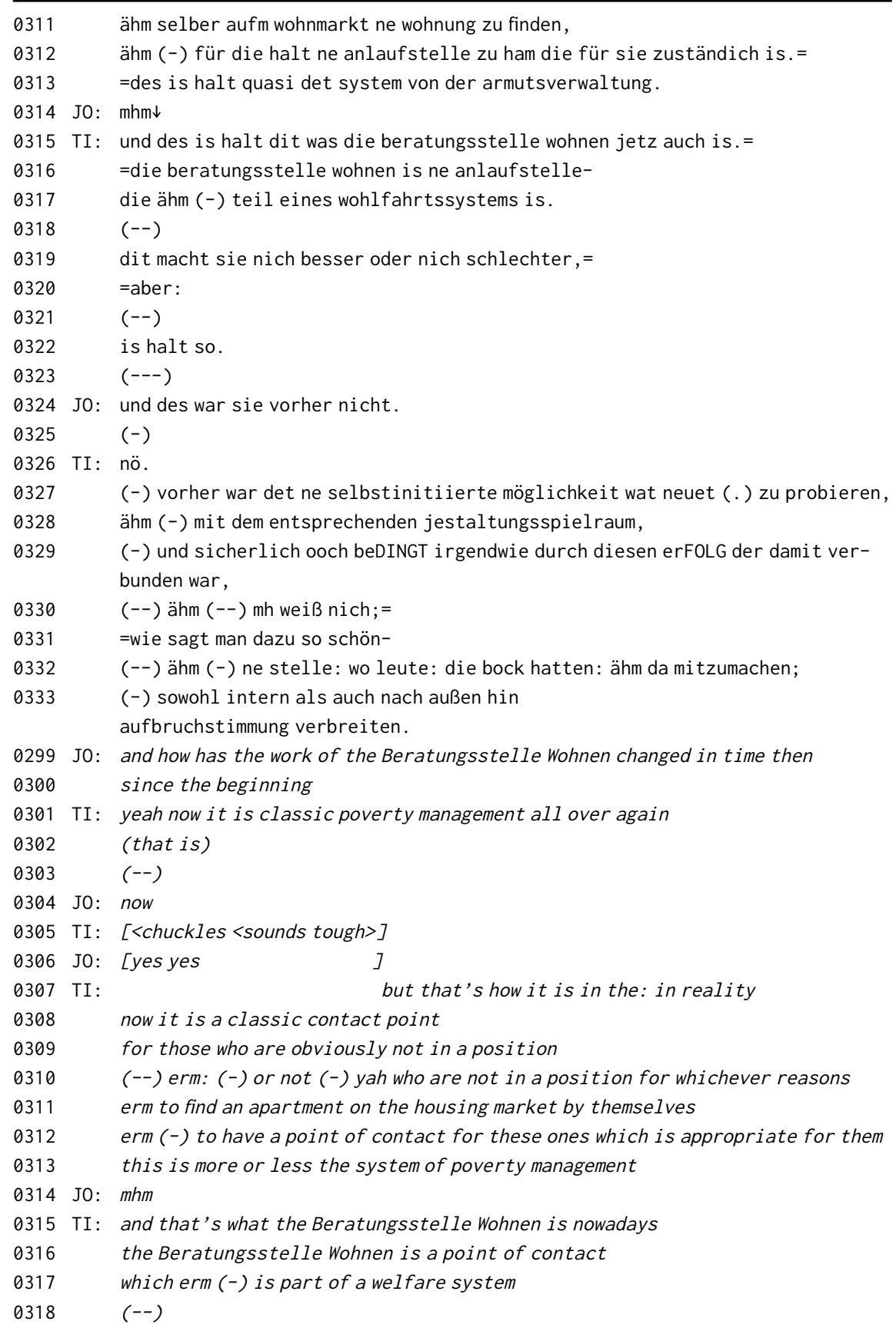


Example 5: (continued)

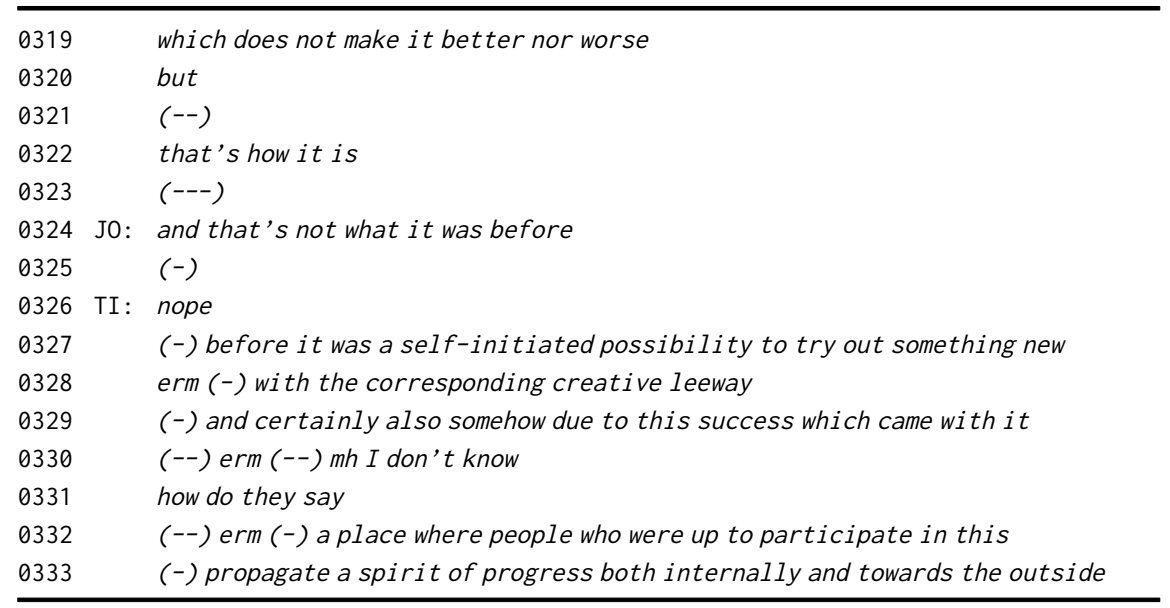

Responding to my question, Till labels the activities at the present-day CC klassische Armutsverwaltung ('classic poverty management', line 0301), implying that this had not always been the case. When I come back to this differentiation (line 0324), he elaborates on the contrast: At the beginning, the project was a more flexible, grass-roots initiative with an orientation towards social change (Aufbruchstimmung, 'spirit of progress'). This reproduces the axis of differentiation established earlier in the interview encounter: On the one side of the spectrum is individual case work ("poverty management" being the relevant example) by which social workers stabilise the capitalist state. On the other side is critical social work which aims at social and political transformation. This axis of differentiation is mapped onto typified forms of practice and corresponding personae in the coconstructed narrative: System-inherent work where the figure of the social worker is part of a structure they can only reproduce, lacking an agency of their own, and system-changing work where the figure of the social worker is a driving force for societal change. And it is mapped onto the history of the CC: then activist interventions which consisted in "try[ing] out something new" (line 0327), now (communicative) service provision on behalf of the state as an Anlaufstelle ('point of contact', lines 0312, 0316). This reflexive analysis matches the one coconstructed by Sara and myself (initiated by my question) which contrasted the staff's orientations towards either questions of (system-inherent) legality or of (system-changing) activism. These exemplary positionings illustrate how the tensions underlying the process of institutionalisation - and reproduced in (meta-) communicative work - affect the workers' understanding of their professional 
agency: namely as being heavily constrained. (Meta-)communicative work may allow for professional agency in situated encounters, but it fails to address the underlying problem - the lack of resources - creating the need for even more (meta-)communicative work. Thus, it also fails to address the workers' sense of lacking agency in what they do.

\section{Conclusions}

We have no apartments. This paper started with the question why the staff at the CC keep repeating this description of an institutional reality that almost all participants - staff, interpreters and clients - know does not match the complexity of institutional life. In order to understand how the function of such a reiterative practice emerges in the institutional context, how it is negotiated and which effects this produces, I followed the recontextualisation of the phrase along the discursive chain. As the phrase becomes part of a perpetuated institutional script in a process of entextualisation, de- and recontextualisation, it establishes a regime of sayability for "frontstage" communication. As we have seen in the reported discussions from staff meetings and in the counselling guidelines, this is the result of strategic choices and of (meta-)communicative work: meta-communicative as it consists in the reflexive regimentation of speech (cf. Carr 2011), and communicative as it is carried out in constant communicative practice, resting on the communicative labour force (or wordforce, Duchêne 2011) of each worker (counsellors as well as volunteers). (Meta-) communicative work as an analytical lens makes the scalar dynamics (Blommaert 2007) of institutional meaning- and boundary-making visible, i.e. how such meaning- and boundary-making is established, negotiated and navigated in situated encounters ("upscaling”, sensu Blommaert 2007). This, in turn, shows how the work of meaning- and boundary-making becomes the onus of the individual worker, "downscaling” the neoliberal governance of welfare by percolating into institutional practices and workers' subjectivities.

As to its effects and functions, the situation exemplifies the "bind" of agency of a post-sovereign subject (see also Lorente 2018: 105): While the reiterated erasure of bits of institutional life constitutes a sort of "black box" secluded from external scrutiny that promises to allow for some sort of professional autonomy in decisionmaking, this erasure comes with all sorts of practical problems deriving from the mismatch between what is said openly and what is said and done under cover. While covering-up allows to carry on the CC's foundational agenda of redistribution on a smaller scale, this comes at the price of "buying into" and enforcing an agenda of self-responsibilisation on the major part of the clients. 
Despite the opposition to government policies aiming at fractioning refugees into hierarchies of “deservingness” (Ataç 2019) and instituting a logic of individual investment and merit (Lehner 2017), the institutional actors are forced into the same logic by their implication in processes of distribution of resources (housing as well as services). This has not only effects on the emergence and reproduction of the figure of the (un)deserving client, but also on that of the professional (cf. Del Percio 2016). The logics derived from the role as distributor of resources effectively enters into conflict with self-professed institutional morals such as advocacy for the clients (cf. de Jong and Ataç 2017). Social work professionalism is therefore under pressure from constitutive contradictions (1) in the counsellors' role as gatekeepers and (2) in their dependence on state funding and the concomitant alignment with trends in welfare policy. The phrase we have no apartments promises to "domesticate" these contradictory conditions, to institutionalise them, which implies their reproduction.

In this article, I propose an analysis of the emergence and negotiation of meaning across discursive events making use of the concept of reiteration. Crucially, the Butlerian notion of reiteration which complements the well-received linguistic anthropological notions of entextualisation, de- and recontextualisation in my use of the concept cast light on the language ideology of the sovereign author-speaker. Therefore, I focused on questions of agency in reiteration by looking at the (meta-)communicative work in which counsellors and volunteers as postsovereign subjects engage as they position themselves in reiterative practice. My analysis thus contributes to an understanding of agency in the ideological and scalar dynamics of meaning-making.

\section{Transcription symbols}

The transcription follows an adaptation of the GAT2 conventions (Selting et al. 2009):

\begin{tabular}{ll}
\hline$()$. & very short pause \\
$(-)$ & short pause \\
$(--)$ & a little longer pause \\
$(---)$ & longer pause \\
$($ segment $)$ & imputed wording \\
$:$ & lengthening of a segment \\
UPPER case & emphasis \\
$<$ laughs <segment〉> & description of paraverbal phenomena \\
[word] & overlapping stretch of talk \\
$=$ & latching \\
. & falling contour
\end{tabular}


(continued)

\begin{tabular}{ll}
\hline$;$ & slightly falling contour \\
- & level contour \\
$?$ & slightly rising contour \\
$\uparrow$ & rising contour \\
$\downarrow$ & rising contour within a prosodic unit \\
\hline
\end{tabular}

Acknowledgments: Special thanks go to the people at the counselling centre for letting me participate in their everyday work. I would also like to thank the guest editors Jürgen Spitzmüller, Brigitta Busch and Mi-Cha Flubacher as well as the journal editors Alexandre Duchêne and Jacqueline Urla for their support. I am also much indebted to two anonymous reviewers, as well as my colleagues Christian Bendl, Alfonso Del Percio, Taegu Kim, Kamilla Kraft, Sabine Lehner, Sara Nyssen, Sandra Radinger, Andrea Sedlaczek, Maiju Strömmer, Sarah Van Hoof and Martina Zimmermann, who commented with a critical eye on earlier versions of this paper. Finally, I want to thank my colleagues Mandana Piroozfar and Nora Al-Awami who helped me to translate and interpret the data in Dari, Farsi and Arabic.

Research funding: This study was supported by Rectorate of Vienna University (Uni:docs fellowship), Research Network of the Austrian Chamber of Labour Vienna, and Municipal Department for Cultural Affairs of the City of Vienna (MA 7 - 474478/16).

\section{References}

Agha, Asif. 2007. Language and social relations. Cambridge: Cambridge University Press.

Ataç, Ilker. 2019. Deserving shelter: Conditional access to accommodation for rejected asylum seekers in Austria, the Netherlands, and Sweden. Journal of Immigrant \& Refugee Studies 17(1). 44-60.

Bauman, Richard. 2004. A world of others' words. Malden: Blackwell.

Bauman, Richard \& Charles L. Briggs. 1990. Poetics and performance as critical perspectives on language and social life. Annual Review of Anthropology 19. 59-88.

Blommaert, Jan. 2007. Sociolinguistic scales. Intercultural Pragmatics 4(1). 1-19.

Boutet, Josiane. 2008. La vie verbale au travail: Des manufactures aux centres d'appels. Toulouse: Octarès.

Bundesministerium für Inneres. 2015. Richtigstellung zum ORF “Report”-Beitrag "Sperrzone Traiskirchen”. https://bmi.gv.at/news.aspx?id=4B415A4777685449494B593D (accessed 6 June 2020).

Bundesministerium für Inneres. 2017. Fremdenrechtsänderungsgesetz 2017 - FrÄG 2017. https:// www.parlament.gv.at/PAKT/VHG/XXV/ME/ME_00279/index.shtml (accessed 5 June 2020). 
Butler, Judith. 1997. Excitable speech. New York: Routledge.

Butler, Judith. 2004. Undoing gender. New York: Routledge.

Carr, E. Summerson. 2011. Scripting addiction. Princeton: Princeton University Press.

Carr, E. Summerson \& Michael Lempert. 2016. Introduction: Pragmatics of scale. In

E. Summerson Carr \& Michael Lempert (eds.), Scale, 1-21. Oakland, California: University of California Press.

Codó, Eva. 2008. Immigration and bureaucratic control. Berlin: Mouton de Gruyter.

de Jong, Sara \& Ilker Ataç. 2017. Demand and deliver: Refugee support organisations in Austria. Social Inclusion 5(3). 28-37.

Del Percio, Alfonso. 2016. The governmentality of migration: Intercultural communication and the politics of (dis)placement in Southern Europe. Language \& Communication 51. 87-98.

Derrida, Jacques. 1972. Signature événement contexte. Marges de la philosophie, 365-393. Paris: Les éditions de minuit.

Dlaske, Kati, Elisabeth Barakos, Kyoko Motobayashi \& Mireille McLaughlin. 2016. Languaging the worker: Globalized governmentalities in/of language in peripheral spaces. Multilingua 35(4). 345-359.

Duchêne, Alexandre. 2011. Néolibéralisme, inégalités sociales et plurilinguisme: l'exploitation des ressources langagières et des locuteurs. Langage et Société 136(2). 81-108.

Duranti, Alessandro. 2006. Agency in language. In Alessandro Duranti (ed.), A companion to linguistic anthropology, 451-473. Malden: Blackwell.

Gal, Susan \& Judith T. Irvine. 2019. Signs of difference. Cambridge: Cambridge University Press.

Goffman, Erving. 1959. The presentation of self in everyday life. New York: Doubleday.

Goodman, Jane E., Matt Tomlinson \& Justin B. Richland. 2014. Citational practices: Knowledge, personhood, and subjectivity. Annual Review of Anthropology 43. 449-463.

Hassemer, Jonas \& Maria Rosa Garrido. 2020. Language as a resource with fluctuating values: Arabic speakers in humanitarian and social work. International Journal of the Sociology of Language 264. 137-161.

Heller, Monica. 2003. Globalization, the new economy, and the commodification of language and identity. Journal of Sociolinguistics 7(4). 473-492.

Lawrence, Thomas B., Roy Suddaby \& Bernard Leca. 2009. Theorizing and studying institutional work. In Thomas B. Lawrence, Roy Suddaby \& Bernard Leca (eds.), Institutional work: Actors and agency in institutional studies of organizations, 1-27. Cambridge: Cambridge University Press.

Lehner, Sabine. 2017. Sprachliches Kapital und 'Integration’: Bourdieus sprachlicher Markt revisited am Beispiel der österreichischen 'Integrationsbotschafter_innen'. Wiener Linguistische Gazette 80. 81-107. https://wlg.univie.ac.at/fileadmin/user_upload/p_wlg/ 852020/Lehner-Ungewissheit.pdf (accessed 19 August 2020).

Lessenich, Stephan. 2008. Die Neuerfindung des Sozialen. Bielefeld: Transcript.

Lorente, Beatriz P. 2018. Scripts of servitude. Bristol: Multilingual Matters.

Luisa Martín Rojo \& Alfonso Del Percio (eds.). 2019. Language and neoliberal governmentality. London: Routledge.

Meinhart, Edith, Martin Staudinger \& Peter Unger. 2018. From empathy to hostility in 127 days: The journey of Austrian press and TV coverage. In Giovanna Dell'Orto \& Irmgard Wetzstein (eds.), Refugee news, refugee politics: Journalism, public opinion and policymaking in Europe, 171-183. New York: Routledge.

Nakassis, Constantine V. 2012. Brand, citationality, performativity. American Anthropologist 114(4). 624-638. 
Pritzker, Sonya E. \& Sabina Perrino. 2021. Culture inside: Scale, intimacy, and chronotopic stance in situated narratives. Language in Society 50(3). 365-387.

Schmidt, Colette M. 2015. Betreuungsfirma Traiskirchen: Wer profitiert hier genau? Kommentar, derStandard. https://www.derstandard.at/story/2000021144255/betreuungsfirma-intraiskirchen-wer-profitiert-hier-genau (accessed 6 June 2020).

Selting, Margret, Peter Auer, Dagmar Barth-Weingarten, Jörg Bergmann, Pia Bergmann, Karin Birkner, Elizabeth Couper-Kuhlen, Arnulf Deppermann, Peter Gilles, Susanne Günthner, Martin Hartung, Friederike Kern, Christine Mertzlufft, Christian Meyer, Miriam Morek, Frank Oberzaucher, Jörg Peters, Uta Quasthoff, Wilfried Schütte, Anja Stukenbrock \& Susanne Uhmann. 2009. Gesprächsanalytisches Transkriptionssystem 2 (GAT 2). Gesprächsforschung 10. 353-402.

Silverstein, Michael. 1976. Shifters, linguistic categories, and cultural description. In Keith Basso \& Henry Selby (eds.), Meaning in anthropology, 11-55. Albuquerque: University of New Mexico Press.

Spitzmüller, Jürgen, Mi-Cha Flubacher \& Christian Bendl. 2017. Soziale Positionierung: Praxis und Praktik. Wiener Linguistische Gazette 81. 1-18. https://wlg.univie.ac.at/fileadmin/user_ upload/p_wlg/812017/spitzmueller-flubacher-bendl-einf.pdf (accessed 19 August 2020).

Urban, Greg. 1996. Entextualization, replication, and power. In Michael Silverstein \& Greg Urban (eds.), Natural histories of discourse, 21-44. Chicago: The University of Chicago Press.

Urciuoli, Bonnie. 2016. Imagining the language worker's language. Multilingua 35(4). 469-481.

Wortham, Stanton \& Angela Reyes. 2015. Discourse analysis beyond the speech event. New York: Routledge. 